\title{
Definitional Dilemma of "Terrorism” under International Law
}

\author{
MUHAMMAD IMRAN \\ ROHAIDA NORDIN
}

\begin{abstract}
Terrorism is not a domestic issue but is instead a global phenomenon. The changing form of terrorism is going to be complex day by day. Every State is facing terrorism, and no State is immune to this disease. None the least, the lack of a universally accepted definition of terrorism is a significant hindrance in developing effective international counter terrorism strategies. The 9/11 attacks in the US have unavoidably shaped the fight against by demanding a rapid and unified reaction from the international community. This Paper examines the meaning of terrorism and also evaluates the definitions of terrorism presented by various scholars. It also highlights the hurdles which are hindering in attaining a universally accepted definition of terrorism. Moreover, the definitions of terrorism by the International bodies such as the United Nations General Assembly, the Security Council, the International Court of Justice and the International Criminal Court are also analysed. The analysis provides a foundation for any future evaluation on definition of terrorism under any domestic counter terrorism laws. This Paper concludes that a universally accepted definition of terrorism is necessary to help in curbing the issue of terrorism globally or domestically.
\end{abstract}

Keywords: Terrorism; universally accepted definition; United Nations; Security Council; counter-terrorism laws

\section{INTRODUCTION}

Terrorism is a serious menace, if not a critical phenomenon globally as almost all countries face this threat. The 9/11 attacks in the US have unavoidably shaped the fight against by demanding a rapid and unified reaction from the international community. However, merely naming organisations as terrorists in the absence of a universally accepted definition of terrorism has problems and becomes a significant hurdle in forming a unified response from the international community.

In combating terrorism, the importance of a universally accepted definition of terrorism is an important factor in creating international cooperation based on current agreed policies relating to conventional war fare. Significant effort has been expended to achieve a universally accepted definition along with several conventions ratified at both international and regional levels. In this regard, the League of the Nation initiated the initial effort where a convention was ratified in 1937, but the draft of this convention was never enforced. Given these struggles, the international community remains incapable of developing a universally accepted definition of terrorism given the different parameters regarding the definition by different countries worldwide. Consequently, different countries are using definitions of terrorism in managing this problem where a variety of definitions of terrorism are seen. Similarly, it has also become a hot topic of scholarly debates where the existing literature identifies over 200 definitions of the term terrorism. ${ }^{2}$ In the book entitled "Political Terrorism," Alex P. Schmid and Albert J. Jongman refer to 109 definitions of terrorism. ${ }^{3}$
Accordingly, given the lack of a universally accepted definition, different administrations may introduce an overly extensive definition of terrorism to criminalise common crimes under this definition. Several Member States of the UN have set their vague domestic definitions of terrorism on the basis of their selfinterests. Consequently, this situation of no supervision from the UN, Pakistan which is also a Member State of the UN has been using its own definition of terrorism within its domestic legislation to combat terrorism that has remained a continuous threat for Pakistan due to a number of reasons.

\section{THE MEANING OF TERRORISM}

The term terrorism is derived from the French word, "Terrorisme," and from the Latinword, "Terrere" which means "to frighten." The concept of a terrorist act has deep roots historically. For instance, during Greek times, different opposite groups repeatedly used the act of terrorism against each other to attain different and certain political objectives. Likewise, terrorism has become an international dilemma for human rights activists globally. ${ }^{4}$

Terrorism has represented the dark side of human attitude throughout history. Moreover, terrorism has continued to pose different threats to the security of societies whether in developing countries or developed countries. It is undeniable that terrorism is a major threat nowadays. It does not mean that terrorists and their victims belong to the same country, as it has been shown that terrorists may belong to different countries and likewise, the victims can be from different countries. 
For terrorist activities, different camps and training academies for terrorists have been well established in different parts of the world in order to train and prepare for terrorists to attack various global targets. ${ }^{5}$ Several attempts have been made to define the word terrorism in many shapes and forms. Likewise, different approaches have been adopted to define and heavily securitised as mentioned next.

\section{SCHOLARLY DEFINITION ON TERRORISM}

According to the Encyclopaedia of Political Thought, word terrorism means "deliberated violence against the government or social system that is designed to strike terror in the citizen or State leaders to accomplish some political change." According to Safire's Political Dictionary, word terrorism has been defined as "Persuasion by the intermediation of society by small groups using as its weapon that society's repugnance at the murder of innocence." The Oxford English Dictionary has defined terrorism as; "the state of terrified is greatly frightened by intense fear, fright and dread." 8

Hoffman defined terrorism as "the deliberate creation and exploitation of fear through violence or the threat of violence in the pursuit of political change." Hoffman tries to distinguish his definition of terrorism from criminal and outrageous ferocity by highlighting the philanthropic and rational characters for the motivation of terrorists. However, it is evident that all actions of terrorism are criminalised as they are eccentric uses of sadistic or intimidating behaviour. ${ }^{10}$

Walter Laqueur defined terrorism as "the illegitimate use of force to achieve a political objective when innocent people are targeted." 11 Likewise, the word "political motivation" is not exclusive of the difficulties in Walter Laqueur's definition of terrorism due to the complicated motivations of a terrorist act. However, substituting the use of force to ferocity can be regarded as the innovation of the definition stated by Walter Laqueur.

According to David J. Whittacker, the word terrorism is defined as "pre-mediated politically motivated uses of violent threats to intimidate the government or the general public." 12 Whittaker emphasises that terrorism is a violent approach that is intended to attain anticipated results by implanting terror and uncertainty and there is intentional use of ferocity against non-combatants. He also states that terrorism is mostly perpetrated by groups and rarely by individuals whereas revolutionary terrorism intends to change the entire set up inside the State. ${ }^{13}$

When the topic of terrorism is considered in international law, the question inexorably arises of how to define terrorism? Various international conventions have been ratified dealing with various facets of terrorism, but in all these conventions, terrorism is defined as a particular subject matter of the specific convention. ${ }^{14}$ Therefore, a universally accepted definition of terrorism cannot be established. Although, Jean-Mark Sorel considers that no perfect definition of terrorism can be given, he attempted to define it byusing the following words, "International terrorism is an illicit act (irrespective of its perpetrator or its purpose) which creates a disturbance in the public order as defined by the international community, by using serious and discriminate violence (in whatever form, whether against people or public or private property) in order to generate an atmosphere of terror with the aim of influencing political action." ${ }^{15}$

According to Schmid and Jongman, "terrorism is an anxiety-inspiring method of repeated violent action, employed by (semi-) Clandestine individual, groups, or State actors, for idiosyncratic, criminal, or political reasons, where buy-in in contrast to assassination are the direct targets of violence which are not the main targets. The immediate human victims of violence are generally chosen at random (targets of opportunity) or selectively (representative or symbolic targets) from a target population, and message generators. Threat and violence-based communication processes between terrorist organisations, imperilled victims, and main targets are used to manipulate the main target audiences, turning it into a terror target, of demands, or a target of attention, depending on whether intermediation, coercion, or propaganda is primarily sought." 16

During the analysis of Schmid and Jongman's definition of terrorism, violence is considered as a paradigm of communication for terrorists. Regardless of the consideration of all aspects of terrorism, Schmid and Jongman's definition of terrorism can be abridged based on the basic elements of terrorism phenomenon since the span of definition clogged the modes of evaluation.

Weinberg, Pedahzur and Hoefler following their analysis of numerous definitions attempted to create a definition as, "terrorism is a politically motivated tactic involving the threat or use of force or violence in which the pursuit of publicity plays a significant role." 17 Weinberg, Pedahzur and Hoefler in their extensive research attempted to offer an appropriate definition by examining 73 definitions extracted from seven related articles. Their definition consisted of five common elements for instance "victim," "actors," "threat or use of force," "publicity" and "achievement of goals." In this case, the definition of terrorism presented by Weinberg, Pedahzur and Hoefler is unambiguous with the ease of consensus.

According to Ben Saul "terrorism is any serious, violent, criminal acts intended to cause death or serious bodily injury, or to endanger life, including by acts against property; whether committed outside an armed conflict; for a political, ideological, religious, or ethnic purpose; and where they are intended to create extreme 
fear in a person, group, or the general public, to seriously intimidate a population or part of a population, or unduly compelling a government or international organisations to do or to abstain from doing any act." ${ }^{18}$ Ben Saul's debate is based on some common elements such as serious violence, motives and objectives, threats to international security and creating extreme fear which imitates certain agreements between countries about the definition of terrorism and therefore, universal agreement is possible.

A review of definitions by terrorism experts show that they are still incapable of reaching a consensus on the definition of terrorism given the variances in the parameters of defining terrorism by different countries for their own benefit. But the "violence" and "force" are common elements of all definition of terrorism. Defining terrorism has always been a challenge since early in the $20^{\text {th }}$ century. A comprehensive definition of terrorism is essential for reaching international consent and also for the formulation of meaningful legislative measures to guard against terrorism. Preparing an appropriate and universally accepted definition of terrorism has become extremely challenging. However, it is not clear that these problems are basically intellectual or political. Extensive terrorism literatures have been concentrated on the debate regarding the difficulties involved in the definition. Although these struggles did not bring about any significant development in the solution to this problem, in the following sections, definitions of terrorism by the UN, Pakistan and the US are examined.

\section{DEFINITIONS OF TERRORISM UNDER INTERNATIONAL LAWS}

The UN is an international organisation, with primary responsibility to encourage international coordination and to sustain international peace and order. The UN was established on 24 October 1945 following the Second World War to prevent future conflict as a substitute of the unproductive League of Nations. The UN consists of 193 Member States and is headquartered in Manhattan New York Cityand with other offices in Geneva Nairobi and Vienna. Voluntary donations from its Member States fund the UNand its primary goals include maintaining international peace and security, promoting human rights, fostering social and economic development, protecting the environment and providing humanitarian aid in cases of famine, natural disasters and armed conflict. Accordingly, the UN is the most powerful intergovernmental organisation globally. ${ }^{19}$

The UN Charter initially drafted at a conference between April and June 1945 in San Francisco and was formally signed on 26 June 1945 after the conference there by becoming operational. The UN consists of six main organs: ${ }^{20}$
1. The General Assembly;

2. The Security Council for deciding certain resolutions for peace and security;

3. Economic and Social Council for promoting international economic and social cooperation and development for the Member States;

4. Secretariat for providing studies information and facilities needed by the UN;

5. The International Court of Justice as the primary judicial organ; and

6. UN Trusteeship Council which is ineffective since 1994.

In early 1970 the UN Adhoc committee was allocated a task to draft a comprehensive convention "to create a precise definition of terrorism." The Adhoc Committee produced several reports highlighting the problems related to the existing definition of terrorism. However, the efforts to create a universal definition failed due to differences among the Member States regarding the parameters surrounding the definition.

The International Law Commission, GA, SC and International Court of Justice tried the path of Gaining consensus on a comprehensive and agreed definition of terrorism. During the 1990s, which marked the end of the Cold War and colonialism in Africa, expectation was revamped to reach a consensus on "a universally accepted definition of terrorism." To this day, 15 international conventions $^{21}$ on terrorism under the supervision of the UN have been ratified. ${ }^{22}$ Definitions of terrorism UN conventions directly related to terrorism are given in the following paragraphs.

\section{UNITED NATIONS CONVENTIONS DIRECTLY RELATED TO TERRORISM}

Before the 9/11 attacks, there were two conventions directly related to terrorism. The first convention is the International Convention for the Suppression of Terrorist Bombings which was adopted in New York on 15 December 1997. The second International Convention for the Suppression of the Financing of Terrorism (1999) was adopted on 9 December 1999 in New York. The International Convention for the Suppression of Acts of Nuclear Terrorism (2005) was the international convention adopted post the 9/11 event.

Article 2(1) of the International Convention for the Suppression of Terrorist Bombings 1997 states that:

\footnotetext{
"Any person commits an offence within the meaning of this convention if that person unlawfully and intentionally delivers, places, discharges or detonates an explosive or other little device into or against or place or public use, a State, a government facility, a public, transportation system or an infrastructure facility with the intent to cause death or serious bodily injury or be with the intent to cause extensive destruction of such a place, facility or system whereas such a destruction results in or is likely to result in major economic loss."
} 
Moreover, Article 2(1) of the International Convention for the Suppression of the Financing of Terrorism 1999 states that:

"Any person commits an offence within the meaning of this Convention if that person by any means, directly or indirectly, unlawfully and willfully, provides or collects funds with the intention that they should be used or in the knowledge that they are to be used, in full or in part, in order to carry out:(a) An act which constitutes an offence within the scope of and as defined in one of the treaties listed in the annex; or (b) Any other act intended to cause death or serious bodily injury to a civilian, or to any other person not taking an active part in the hostilities in a situation of armed conflict, when the purpose of such act, by its nature or context, is to intimidate a population, or to compel a government or an international organisation to do or to abstain from doing any act."23

Although these definitions express different approaches towards terrorism through the lens of armed conflict, regardless of this dissimilarity, individual criminal accountability is the common element in the definition provided by the conventions mentioned above.

The International Convention for the Suppression of Acts of Nuclear Terrorism which was adopted following the 9/11 attacks defining terrorism in Article 2 as:

"Any person commits an offence within the meaning of this Convention if that person unlawfully and intentionally: (a) Possesses radioactive material or makes or possesses a device: (i) With the intent to cause death or serious bodily injury; or (ii) With the intent to cause substantial damage to property or to the environment; (b) Uses in any way radioactive material or a device, or uses or damages a nuclear facility in a manner which releases or risks the release of radioactive material: (i) With the intent to cause death or serious bodily injury; or (ii) With the intent to cause substantial damage to property or to the environment; or (iii) With the intent to compel a natural or legal person, an international organisation or a State to do or refrain from doing an act." ${ }^{24}$

The rest of the conventions do not define terrorism but simply focus on particular kinds of terrorism or activities related to terrorists.

\section{THE UNITED NATIONS GENERAL ASSEMBLY (GA)}

The GA is one of the six main organs of the UN in which all Member States have equal representation by "one Nation one vote." It is the main premeditated, policymaking and representative organ of the UN. All 193 Member States of the UN are represented in this unique forum under the UN Charter. Decisions on important questions such as peace, security, admittance of new members and related to budgetary issues need a twothirds majority ruling of the 193 UN Member States while decisions on other questions are simply made by majority votes. ${ }^{25}$
The GA has issued many resolutions related to terrorism; with five most important resolutions are discussed in the following sections.

$\mathrm{A} / \mathrm{RES} / 44 / 29^{26}$

The $72^{\text {nd }}$ Plenary Meeting of GA on 4 December 1989 emphasised the approaches to prevent international terrorism which risk or takes innocent human life and risks their fundamental rights. It analyses the fundamental grounds of those kinds of terrorism and acts of violence which create frustration and grievance which compel them to sacrifice human life. However, despite recognising international terrorism as a grave threat tointernational peace and security, this resolution has not defined terrorism. ${ }^{27}$

\section{$\mathrm{A} / \mathrm{RES} / 49 / 60^{28}$}

The $84^{\text {th }}$ Plenary Meeting on 9 December 1994 annexed the GA Resolution No. 49/60 which is the GA significant resolution but adopts a criminal approach to terrorism: "Criminal acts intended or calculated to provoke a state of terror in the general public a group of persons or particular persons for political purposes or in any circumstance unjustifiable whatever the considerations of a political, philosophical, ideological, racial, ethnic, religious, or any other nature that may be invoked to justify them." 29

\section{$\mathrm{A} / \mathrm{RES} / 51 / 210^{30}$}

$\mathrm{A} / \mathrm{RES} / 51 / 210$ in the $88^{\text {th }}$ Plenary Meeting on 17 December 1996, the GA by recalling its Resolution 49/60 stressed instead on the measures to eliminate international terrorism by defining within Title I in Section 2, the following words "criminal acts intended or calculated to provoke a state of terror in the general public, a group of persons or particular persons for political purposes are in any circumstance unjustifiable, whatever the considerations of a political, philosophical, ideological, racial, ethnic, religious or other nature that may be invoked to justify them." 31 The GA in this resolution established an Adhoc Committee to draft a comprehensive convention on terrorism, but unfortunately, to date, there has been no universally agreed convention. ${ }^{32}$

\section{$\mathrm{A} / \mathrm{RES} / 54 / 109^{33}$}

The GA adopted the International Convention for the Suppression of the Financing of Terrorism through Resolution 54/109 on 9 December 1999 being extremely concerned about the global increase in acts of terrorism. It defines terrorism as a criminal and unjustifiable act, defining terrorism under Article 2(1) as:

"Any person by any means directly or indirectly unlawfully and willfully provides or collects funds with the intention that 
they should be used or in the knowledge that they are to be used in full or in part in order to carry out (a) an act which constitutes an offence within the scope of and as defined in one of the treaties listed in the Annex; or (b) any other act intended to cause death or serious bodily injury to a civilian, or any other person not taking an active part in the hostilities in a situation of armed conflict when the purpose of such an act by its nature or context is to intimidate a population or to compel a government or an international organisation to do or to abstain from doing an act." It does not particularly refer to acts of violence but refers to criminal acts." ${ }^{34}$

\section{$\mathrm{A} / \mathrm{RES} / 59 / 565^{35}$}

The GA in Resolution 59/565 of 2 December 2004 offered some necessary elements for the definition of terrorism. The GA stated that any definition of terrorism should include these four essential elements.

1. Recognition in the preamble, stating that the use of force against civilians is regulated by the Geneva Conventions II, III, IV and other instruments and if of sufficient scale, constitutes a war crime by the persons concerned or a crime against humanity;

2. Restatement that acts under the 12 preceding anti-terrorism conventions are terrorism, and a declaration that they are a crime under international law; and restatement that terrorism in a time of armed conflict is prohibited by the Geneva Convention and the Additional Protocols;

3. Reference to the definitions contained in the 1999 International Convention for the Suppression of the Financing of Terrorism and SC Resolution 1566 (2004); and

4. Description of terrorism as "any action, in addition to actions already specified by the existing conventions on aspects of terrorism, the Geneva Convention and SC Resolution 1566 (2004), that is intended to cause death or serious bodily harm to civilians or non-combatants, when the purpose of such an act, by its nature or context, is to intimidate a population, or to compel a government or an international organisation to do or to abstain from doing any act."36

\section{THE UNITED NATIONS SECURITY COUNCIL (UNSC)}

The UNSC has the primary responsibility for the maintenance of international peace and security. The SC consists of 15 Members States which include five permanent members (i.e. China, France, UK, US, the Russian Federation) and 10 non-permanent Member States. Under Articles 25 and 48 of the UN Charter, the SC is authorised for the establishment of peacekeeping operations and the establishment of international sanctions and the authorisation of military action through $\mathrm{SC}$ resolutions. It is the only UN organ having the authority to issue binding resolutions to the UN Member States. ${ }^{37}$
Following the 9/11 attacks, the SC took significant measures to combat terrorism by condemning international terrorism. The SC also recognised the right of self-defence under Article 51 of the UN Charter which provides that:

"Nothing in the present Charter shall impair the inherent right of individual or collective Self-defence if an armed attack occurs against a member of the UN until the Security Council has taken measures necessary to maintain international peace and security. Measures taken by members in the exercise of this right of self-defence shall be immediately reported to the Security Council and shall not in any way affect the authority and responsibility of the Security Council under the present charter to take at any time such action as it deems necessary in order to maintain restore international peace and security."

Definitions of terrorism under UNSC resolutions related to terrorism are given in the following paragraphs:

\section{SC RESOLUTION NO.1368}

The UNSC Resolution 1368 was adopted unanimously on 12 September 2001 in the $4,370^{\text {th }}$ meeting of the SC. The SC strongly condemned the $9 / 11$ attacks after expressing its determination to counter threats to international peace and security created by acts of terrorism and also recognised the right of individual and collective selfdefence. This Resolution 1368, however, does not have any provision on the definition of terrorism. However, the resolution stress on combating terrorism, considering it a serious threat. The SC condemned the $9 / 11$ attacks through Resolution 1368 through paragraph 1 using the following words:

"Unequivocally in the strongest terms the horrifying terrorist attacks which took place on $11^{\text {th }}$ September 2001 in New York, Washington, D.C. and Pennsylvania and regards such acts, like any act of international terrorism, as a threat to international peace and security." ${ }^{38}$

This resolution provided basis for further action to cope with the international terrorism. Resolution 1368 provided international legitimacy for armed action against the perpetrators and supporters of the $9 / 11$ attacks. This resolution confirms that any act of international terrorism threat to international peace and security. Arguably, however, if an act of terrorism lacks international dimension, it remains irrelevant to the UNSC.

\section{SC RESOLUTION NO.1373}

The SC Resolution 1373 was adopted unanimously on 28 September 2001 in its $4,385^{\text {th }}$ meeting under the UN Chapter VII and therefore, binding all UN Members States. It also established the CTC. Although Resolution 1373 does not contain a definition of terrorism, it directed to deter terrorist groups in several ways by encouraging the UN Member States to share their intelligence regarding terrorist organisations to assist in encountering international terrorism. This resolution also called on the 
UN Member States to modify their national laws so that they could ratify all existing international conventions on terrorism.

Furthermore, it declared that all States "should also ensure that terrorist acts are established as serious criminal offences in domestic laws and regulations and that the seriousness of such acts is duly reflected in sentences served." 39 It also aimed at constraining immigration laws declaring that:

"Before granting refugee status, all States should take appropriate measures to ensure that the asylum seekers had not planned facilitated or participated in terrorist acts. Further, States should ensure that refugee status was not abused by the perpetrators, organisers or facilitators of terrorist acts and that claims of political motivation were not recognised as grounds for refusing requests for the extension of alleged terrorists. ${ }^{\circ 0}$

Although, the resolution emphasised the legislative cooperation between the Member States to counter terrorism, however, it failed to offer a standard definition of terrorism for the national legislation of the Member States. As a result, different legal definitions of terrorism have been adopted by the UN Member States which are contradictory with the objectives of Resolution 1373 to enhance international cooperation to counter terrorism. ${ }^{41}$

\section{SC RESOLUTION NO 1540}

The UNSC Resolution 1540 was passed in its $4,956^{\text {th }}$ meeting on 28 April 2004, regarding the non-proliferation of weapons of mass destruction. Under Chapter VII of the UN Charter, this resolution establishes the obligation for all its Member States to improve and enforce suitable legal and regulatory measures against the "proliferation of chemical, biological, radiological and nuclear weapons and their means of delivery specific to nonstate actors. ${ }^{\prime 42}$

The SC Resolution 1540 is only the second resolution which refers to Chapter VII without concerning the fact to a "specific time and place," after the SC Resolution 1373. The risk of terrorists accessing weapons of mass destruction was previously considered in paragraphs 3(a) and 4 of Resolution 1373. The three primary obligations under this resolution include the following:

1. To refrain from providing any form of support to non-state actors that attempt to develop, acquire, manufacture, process, transport, transfer or use chemical or biological weapons and their means of delivery(Article 1).

2. To adopt and enforce appropriate effective laws which prohibit any non-state actor from manufacturing acquire possess develop transport transfer or use nuclear chemical or biological weapons and their means of delivery (Article 2).

3. To take and enforce effective measures to establish domestic controls to prevent the qualification of nuclear chemical or biological weapons and their means of delivery (Article 3).

This resolution is obligatory for all Member States of the UN and also stresses the continuing importance of non-proliferation. This armament agreement established an Adhoc committee known as the 1540 Committee to supervise the implementation of this resolution. ${ }^{43}$

\section{SC RESOLUTION NO.1566}

The UNSC Resolution 1566 was adopted unanimously on October 2004 in its $5053^{\text {rd }}$ meeting. This resolution condemned terrorism and considering it a serious threat to international peace and security. The SC called on the Member States to prosecute or extradite any person assisting in terrorist acts or taking part in the planning of such acts. Under Chapter VII of the UN Charter, a working group was established to criminalise measures taken by "individuals, groups all entities involved in or associated with terrorist activities" other than Al-Qaeda and the Taliban.

This resolution called upon the Member States to corporate fully with the CTC established under Resolution 1373 (2001) including the Counter Terrorism Committee Executive Directorate (CTED), the Al-Qaeda/Taliban Sanctions Committee established under Resolution 1267 (1999) and its analytical support, the sanctions monitoring team and the committee established under Resolution 1526 (2004). ${ }^{44}$ Article 3 defines terrorism as:

"criminal acts, including against civilians, committed with the intent to cause death or serious bodily injury, or taking of hostages, with the purpose to provoke a state of terror in the general public or in a group of persons or particular persons, intimidate a population or compel a government or an international organisation to do or to abstain from doing any act."

The definition of terrorism in Resolution 1566 is similar to the definition of terrorism in Article 2(1) of the International Convention for the Suppression of the Financing of Terrorism (1999). This definition is the most authoritative definition of terrorism presented in international society. ${ }^{45}$

\section{SC RESOLUTION NO.1526}

The UNSC Resolution 1526 was adopted unanimously on 30January 2014 in its $4,908^{\text {th }}$ meeting after recalling Resolutions 1267 (1999), 1333 (2000), 1363 (2001), 1373 (2001), 1390 (2001), 1452 (2002) and 1455 (2003).

Resolution 1526 was adopted concerning the threats to international peace and security caused by terrorist acts. The SC through this resolution tightened sanctions against Al Qaeda, the Taliban and associated groups. Under Chapter VII of the UN Charter, the SC decided to enhance the implementation of sanctions including the freezing of financial assets and funds possessed by the Taliban, Al 
Qaeda and other associated groups. Analytical support and sanction monitoring team was established to assist the $1,267^{\text {th }}$ committee in fulfilling its mandate for an initial period of 18 months.

This resolution insisted that all Member States of the UN co-operate with the monitoring team and committee by emphasising the need for exchange of intelligence and providing the names of "individuals and entities" that need to be sectioned. ${ }^{46}$

\section{INTERNATIONAL COURT OF JUSTICE (ICJ)}

The ICJ is the principal judicial branch of the UN which is located in Hague, Netherlands. It was established for the sole purpose of resolving legal disputes between States and of giving opinions on legal questions referred to it by international agencies and organs of the GA.

For instance, the ICJ ruled that the US secret war against Nicaragua was unjustifiable in Nicaragua $v$ the United States (Nicaragua case) ${ }^{47}$ Hence, the US withdrew from mandatory jurisdiction in 1986 to accept the court's jurisdiction. Chapter XIV of the UN Charter empowers the UNSC to enforce court judgments. Such enforcement is dependent on the veto powers of the five permanent members of the SC which the US utilised in Nicaragua's case. The ICJ ruled in favour of Nicaragua in the case and accolade compensations to Nicaragua. The ICJ said that the US by using force against Nicaragua violated international laws regarding the use of force and criteria of necessity and proportionality was also not fulfilled. ${ }^{48}$

\section{INTERNATIONAL LAW COMMISSION (ILC)}

The ILC was established by the GA under Article 13(1) (a) of UN Charter and GA Resolution A/RES/174(II) to "initiate studies and make recommendations for the purpose of encouraging the progressive development of international law and its codification." ${ }^{\prime 49}$ At its $43^{\text {rd }}$ session in 1991, the Commission adopted on first reading the draft code of crimes against the peace and security of humanity which included the following crimes:

"aggression; threat of aggression; intervention; colonial domination and other forms of alien domination; genocide; apartheid; systematic or mass violations of human rights; exceptionally serious war crimes; recruitment, use, financing and training of mercenaries; international terrorism; illicit traffic in narcotic drugs; and wilful and severe damage to the environment." ${ }^{50}$

Although the convention criminalises threats and attempts to commit an attack and participation as a supporter in the crime, arequirement which the ILC employed regarding crimes against humanity, the acts "instigated or directed by government or by any organisation or group" werenot incorporated in the definition.

The ILC contemplated terrorism in the $1954 \mathrm{draft}$ Code of Crimes against the Peace and Security of
Mankind, Part 1. However, the draft code was never adopted as in the form of a Treaty. This draft code associates terrorism with "aggression." Under Article1, the crimes include; those performed by "State actors" excluding the terrorist acts performed by "non-state actors." However, terrorist acts were regarded as acts directed against other States.

In the final text adopted at the $48^{\text {th }}$ session in 1996 , the offence of international terrorism was eradicated and examined within the notion of war crimes. It reveals the hugely politicised nature of the terrorism concept and states; this condition is the result of the fact that, until the judgement of the Nuremberg Tribunal, ${ }^{51}$ the word crime was technically not taken in the term of war crimes specifically entailing the most severe range of criminal offences. However, in the general meaning, an offence was defined explicitly as the non-fulfilment of an obligation set out under criminal law irrespective of the seriousness of such non-fulfilment. Therefore, the ILC considered it necessary to elevate the scale of seriousness that a war crime must qualify as a "crime against the peace and security of mankind." Therefore, its condition is an act committed in an organised manner" or on a vast level. ${ }^{52}$

\section{INTERNATIONAL CRIMINAL COURT (ICC)}

The ICC is an inter-governmental organisation that came into effect on 1July 2002, the same date when the Rome Statute became into force. The Rome Statute is a multilateral treaty which serves as the foundational document for the ICC. Currently, 123 States being party to the Rome Statute are members of the ICC. The ICC consists of four main organs: the presidency, the judicial divisions, and the office for the prosecutor and the registry. ${ }^{53}$

Article 5 of the Rome Statute limited the jurisdiction of the ICC to the crime of genocide, crimes against humanity, war crimes and crime of aggression. Terrorism is not mentioned as verified by the following provisions "the jurisdiction of the court shall be limited to the most serious crimes of concern to the international community as a whole. The court has jurisdiction in accordance with this statute concerning the following crimes: (a) the crimes of genocide; (b) crimes against humanity; (c) war crimes; (d) the crime of aggression." 54

The purpose of restricting the ICC jurisdiction to the said four crimes was to legitimise the role and work of the court and also to prevent conflict with the national Court's jurisdictions. However, some debates existed regarding the extent of the ICC's jurisdictions to other selected treaty crimes such as terrorism crimes involving "illicit trafficking in narcotic drugs and crimes against UN and associated personnel." Despite numerous efforts and opinions, the acts of terrorism are still not part of the ICC's current jurisdictions. ${ }^{55}$ 


\section{ANTI-TERRORISM CONVENTIONS AT INTERNATIONAL AND REGIONAL LEVEL}

Despite the struggling, the GA has not yet succeeded in reaching a universally accepted definition of terrorism.
However, despite the unproductive attempts of the GA to reach a consensus on the definition, its struggles to ratify several anti-terrorism conventions are appreciable. ${ }^{56}$ The international anti-terrorism conventions ratified under the GA platform are shown in the table below.

TABLE 1 Anti-Terrorism Conventions at International Level

\begin{tabular}{|c|c|c|}
\hline Convention & Date of Enactment & Date of Enforcement \\
\hline Convention on Offences and Certain other Acts Committed on Board Aircraft & 14 September 1963 & 4 December 1969 \\
\hline Convention for Suppression of Unlawful Seizure of Aircraft & 16 December 1970 & 14 October 1971 \\
\hline $\begin{array}{l}\text { Convention for the Suppression of Unlawful Acts against the Safety } \\
\text { of Civil Aviation }\end{array}$ & 23 September 1971 & 26 January 1973 \\
\hline $\begin{array}{l}\text { Convention on the Prevention and Punishment of Crimes against Internationally } \\
\text { Protected Persons, including Diplomatic Agents }\end{array}$ & 14 December 1973 & 20 February 1977 \\
\hline International Convention against the Taking of Hostages & 17 December 1979 & 3 June 1983 \\
\hline $\begin{array}{l}\text { Convention on the physical Protection of Nuclear Material } \\
\text { and }\end{array}$ & 3 March 1980 & $\begin{array}{l}8 \text { February } 1987 \\
\text { and }\end{array}$ \\
\hline $\begin{array}{l}\text { Amendment to the Convention on the Convention on the physical Protection } \\
\text { of Nuclear Material }\end{array}$ & & 8 July 2005 \\
\hline $\begin{array}{l}\text { Protocol for the Suppression of Unlawful Acts against the Safety } \\
\text { of Fixed Platforms Located on the Continental Shelf }\end{array}$ & 10 March 1988 & 1 March 1992 \\
\hline \multicolumn{3}{|l|}{ Protocol for the Suppression of Unlawful Acts of Violence at } \\
\hline $\begin{array}{l}\text { Airports Serving International Civil Aviation, Supplementary } \\
\text { to the Convention for the Suppression of Unlawful Acts against } \\
\text { the Safety of Civil aviation. }\end{array}$ & 24 February 1988 & 6 August 1989 \\
\hline Convention on the Marking of Plastic Explosives for the Purpose of Detection & 1 March 1991 & 21 June 1998 \\
\hline International Convention for the Suppression of Terrorist Bombings & 15 December 1997 & 23 May 2001 \\
\hline International Convention for the Suppression of the Financing of Terrorism & 9 December 1999 & 10 April 2002 \\
\hline $\begin{array}{l}\text { Protocol of } 2005 \text { to the Convention for the Suppression of Unlawful } \\
\text { Acts against the Safety of Maritime Navigation }\end{array}$ & 14 October 2005 & 28 July 2008 \\
\hline International Convention for the Suppression of Acts of Nuclear Terrorism & 13 April 2005 & 7 July 2007 \\
\hline $\begin{array}{l}\text { Convention on the Suppression of Unlawful Acts Relating to International } \\
\text { Civil Aviation }\end{array}$ & 10 September 2010 & 1 July 2018 \\
\hline
\end{tabular}

Source: Developed by Researcher from Analysis of Anti-terrorism Conventions at International Level.

The anti-terrorism conventions have also been rectified at the regional level as follows:

TABLE 2 Anti-Terrorism Conventions at Regional Level

\begin{tabular}{|c|c|c|}
\hline Convention & Date of Enactment & Date of Enforcement \\
\hline European Convention on the Suppression of Terrorism & 27 January 1977 & 4 August 1978 \\
\hline $\begin{array}{l}\text { OAS Convention to Prevent and Punish Acts of Terrorism } \\
\text { Taking the Form of Crimes against Persons and Related } \\
\text { Extortion that are of International Significance }\end{array}$ & 2 February 1971 & 16 October 1973 \\
\hline $\begin{array}{l}\text { South Asian Association for Regional Cooperation (SAARC) } \\
\text { Regional Convention on Suppression of Terrorism }\end{array}$ & 4 November 1987 & 22 August 1988 \\
\hline Arab Convention on the Suppression of Terrorism & 22 April 1998 & 7 May 1999 \\
\hline $\begin{array}{l}\text { Convention of the Organisation of the Islamic } \\
\text { Conference on Combating International Terrorism }\end{array}$ & 1 July 1999 & 7 November 2002 \\
\hline $\begin{array}{l}\text { OAU Convention on the Prevention and Combating of } \\
\text { Terrorism }\end{array}$ & 14 July 1999 & 6 December 2002 \\
\hline $\begin{array}{l}\text { Protocol to the OAU Convention on the Prevention } \\
\text { and Combating of Terrorism }\end{array}$ & 8 July 2004 & 2 February 2010 \\
\hline $\begin{array}{l}\text { Additional Protocol to the SAARC Regional Convention on } \\
\text { Suppression of Terrorism, adopted at Islamabad }\end{array}$ & 6 January 2004 & 12 January 2006 \\
\hline $\begin{array}{l}\text { Shanghai Convention on Combating Terrorism, Separatism } \\
\text { and Extremism }\end{array}$ & 15 June 2001 & 29 March 2003 \\
\hline
\end{tabular}




\author{
Treaty on Cooperation among States Members of the \\ Commonwealth of Independent States in \\ Combating Terrorism \\ 4 June 1999
}

3 June 2002

16 May 2005

16 May 2005

28 May 2007

28 February 2009

4 May 2004

13 January 2007

12 September 2001
October 2000 for Tajikistan;

5 December 2000 for Kazakhstan;

6 February 2001 for Kyrgyzstan;

22 August 2001 for Republic of Moldova;

28 December 2001 for Armenia;

18 April 2004 for Belarus;

and on 13 January 2005 for the Russian

Federation

10 July 2003

1 June 2007

1 May 2008

and Confiscation of the Proceeds from Crime and on the

Financing of Terrorism

OAS Declaration on Strengthening Cooperation in

the Fight against Terrorism and the Impunity

of its perpetrators, 2007

SAARC Ministerial Declaration on Cooperation

in Combating Terrorism

Cooperation Council for the Arab States of the

Gulf (GCC) Convention against Terrorism

ASEAN Convention on Counter Terrorism

Declaration of the Committee of Ministers on

the fight against International Terrorism

Source: Developed by Researcher from Analysis of Anti-terrorism Conventions at Regional Level.

While studying the conventional definitions of terrorism, two collective elements within the definitions include (an objective element and a subjective element). A mixture of objective and subjective elements can also be employed but are not prevalent.

Objective elements attempt to explain terrorism by defining terrorist actions. Most of the conventions regarding terrorism exclude the International Convention for the Suppression of Financing Terrorism which employs the objective approach. However, the flaw of the objective approach is due to its inflexibility as compared to the variable nature of modern approaches regarding terrorism. Most of the countries, for instance, the US, UK, EU and Canada in their domestic laws have employed the subjective approach of the definition. From this approach, the purpose and name of the entity using such ferocity need to be determined. Moreover, the majority of the regional anti-terrorism conventions employ subjective approaches comprising of the Organisation of American States (OAS), Commonwealth Independent States (CIS) and Organisation of Islamic Conference (OIC), Organisation of African Union Convention on the Prevention and Combating Terrorism and the Arab Convention on the Suppression of Terrorism. All have applied subjective scales to define terrorism, before explaining the various kinds of terrorism.

Furthermore, before explaining the various kinds of terrorism, the conventions mentioned above employ subjective elements to define terrorism. However, there are only two conventions that use an objective scale, i.e. the European Union Convention on the Suppression of
Terrorism and the SAARC convention on the Suppression of Terrorism.

According to Article 1 of the SAARC Convention on the Suppression of Terrorism under the requirements of the law of extradition, the offences described within Article 1(e) and (f) are considered as terrorist acts and will not be Investigating as a political offence or associated with political offence or as political motivations for extradition. Also, any crime that falls under the span of the Convention for the Suppression of Unlawful Seizure of Aircrafts signed at Hague on 16 December 1970,or falls within range of the Convention for the Suppression of Unlawful Acts Against the Safety of Civil Aviation signed at Montreal on 23 September 1971, orcomes within the range of the Convention on the Prevention and Punishment of Crimes Against Internationally Protected Persons, including Diplomatic Agents signed at New York on 14 December 1973 shall be considered as a terrorist offence. The offence shall also be considered a terroristic offence if it falls in the range of any conventions to which the SAARC Member States concerned are parties, and which oblige its parties to prosecute or grant extradition as per Article 1(a), (b), (c) and (d).

Within Article 1(e) and (f), it includes "murder, manslaughter, assault causing bodily harm, kidnapping, hostage taking and offences relating to firearms, weapons, explosives and dangerous substances when used as a means to perpetrate, indiscriminate, or enact violence involving death or serious bodily injury to persons or causing serious damage to property" or any attempt or conspire to commit all aforementioned 
offences will be Investigating as a terrorist offence..$^{57}$ In this case, the SAARC Convention on the Suppression of Terrorism used an objective approach in its definition.

According to the European Convention on the Suppression of Terrorism, for the purpose of extradition between contracting States,following offences shall be Investigating as a political offence or as an offence connected with a political offence or as an offence inspired by political motives under Article 1(a) and (b) that falls within the span of the Convention for the Suppression of Unlawful Seizure of Aircrafts signed at the Hague on 16 December 1970 or within the range of the Convention for the Suppression of Unlawful Acts Against the Safety of Civil Aviation signed at Montreal on 23 September 1971. ${ }^{58}$ According to Article 1(c) and (d), an offence will be considered as a terroristic offence if it is involved in attacking the life, physical integrity or independence of internationally secured individuals as well as political agents or kidnapping or taking of a hostage or intense illegal confinement. According to Article 1(e) and (f), the use of a bomb, grenade, and rocket, automatic firearm, letter or parcel bomb to imperil individuals or any attempt to commit the offences mentioned above will be Investigating as a terroristic offence. The European Convention on the Suppression of Terrorism also uses an objective approach in its definition of terrorism.

The International Convention for the Suppression of Financing of Terrorism has employed the subjective approach to define terrorism in its Article 2. A combination of subjective and objective elements has also been employed in the domestic laws of various States such as Article 421(1) of the French Penal Code. ${ }^{59}$ Additionally, the definitions of terrorism provided by the Treaty on Cooperation Among the Members States of the Commonwealth of Independent States in Combating Terrorism, the Organisation of African Union Convention on the Prevention and Combating Terrorism and the Convention of the OIC on Combating International Terrorism and the Arab on the Suppression of Terrorism employed the mixing scale or a combination of subjective and objective elements in their definition.

Accordingly, only three conventions have a definition of terrorism in their provisions i.e. the International Convention for the Suppression of Terrorist Bombings, the International Convention for the Suppression of the Financing of Terrorism and the International Convention for the Suppression of Acts of Nuclear Terrorism. The International Convention for the Suppression of Financing of Terrorism provides a common definition whereas the other two emphasised the particular kinds of terrorism definition. The definitions of terrorism provided by the international and regional anti-terrorism conventions and the UN resolutions can be Investigating as a customary international law. ${ }^{60}$

\section{CONCLUSION}

Terrorism is not a new phenomenon and is as old as human civilisation. Evaluating the history of terrorism helps to put terrorism into perspective and acknowledging the reasons for its emergence as it is today. The review of existing literature on terrorism has highlighted and revealed many modifications to the concept of terrorism. Therefore, it is imperative to reach a consensus on the definition of terrorism in helping to formalise an international strategy to combat terrorism. Importantly, a universally accepted definition of terrorism will help to form the foundation and effective means for escalating an effective approach adapted by international communities to counter-terrorism. Furthermore, it will assist State in establishing strict penalties against those persons who commit, assist and promote terrorism. It will also permit in enacting anti-terrorism laws and to ratify international conventions against terrorist groups, State supporting or assisting terrorism and monetary companies involved in financing them.

It is also suggested that a comprehensive debate is undertaken under the banner of the UN and a definition of terrorism be agreed to put aside States' self-interests. Moreover, given the lack of a universally accepted definition under international laws, several States are indulged in State terrorism and State-sponsored terrorism by using force to repress the human rights of self-determination, societal and financial justice. In future, the unavoidable use of nuclear, biological and chemical weapons and suicide attacks may become common practice by terrorist groups. Therefore, international society should refrain from adopting dual standards and must keep aside self-interests in overcoming terrorism. Moreover, the causes which support and breed terrorism must be eradicated.

\section{NOTES}

United Nations Office on Drugs and Crime, Defining Terrorism, 2018, https://www.unodc.org /e4j/en/terrorism/module-4/keyissues/defining-terrorism.html $>$ accessed (12 January 2019).

2 R. Jackson, 'In Defence of 'Terrorism': Finding a Way through a Forest of Misconceptions' (2011) 3 (2) Behavioral Sciences of Terrorism and Political Aggression, pp 116-130.

3 A. P. Schmid et al, Political Terrorism: A Research Guide to Concepts, Theories, Data Bases and Literature, Transaction Publishers Rutgers, New Jersey, 2005, p 5.

4 A. Moghadam, etal, The Roots of Terrorism. Infobase Publishing, 2006.

5 J. Ciment, World Terrorism: an Encyclopedia of Political Violence from Ancient Times to the Post-9/11 era, Routledge, 2015.

6 I. Abbasi, et al, 'An Overview of the Political Theories of Terrorism' (2014) 19IOSR Journal of Humanities and Social Science, pp 103-107.

L. E. Wyper, 'Transformative Leadership and Diversity: The Need for Change Agents, Followership, and Tipping Points in Our Educational Institutions' (2014) 4 (1) Journal of Global Citizenship \& Equity Education, pp 4-5.

8 B. Bowden, 'The Terror (s) of our Time (s)' (2007) 13 (4) Social Identities, pp 541-554.

9 B. Hoffman, 'Terrorism Trends and Prospects' (1999) 7countering the new terrorism, $\mathrm{p} 13$. 
10 M. G. Marshall, Global Terrorism: an Overview and Analysis, Center for International Development and Conflict Management, University of Maryland, College Park, 2002, p 37.

11 C. A. Coady, 'Terrorism and Innocence' (2004) 8 (1) The Journal of Ethics, pp 37-58.

12 D. J. Whittacker, Terrorist and Terrorism in the Contemporary World, Routledge, UK, 2004, pp 1-2.

13 D. J. Whittacker, Terrorist and Terrorism in the Contemporary World, pp 9-15.

14 J. M. Sorel, 'Some Question about the Definition of Terrorism and the Fight against Its Financing' (2003) 14 (2) European Journal of International Law (EJIL), pp 366-369.

15 J. M. Sorel, 'Some Question about the Definition of Terrorism and the Fight against Its Financing' pp 370-371.

16 C. P. Schmid et al, Political Terrorism, A New Guide to Actors, Authors, Concept, Databases, Theories, and Literature, p 28.

17 L. Weinberg., A. Pedahzur, \& S. Hirsch-Hoefler, 'The Challenges of Conceptualizing Terrorism' (2004) 16 (4) Terrorism and Political Violence, pp 777-794.

18 B. Saul, Defining Terrorism in International Law. Oxford University Press, New York. 2006. pp 65-66.

19 The United Nations, The United Nations Emerged after World War II as an International Peacekeeping Organization. https://www.khanac ademy.org/humanities/us-history/rise-to-world-power/us-wwii/a/ the-united-nations $>$ accessed (24 June 2019).

20 Article 7, the United Nations Charter.

21 Table 1: Anti-Terrorism Conventions at International Level, of this Manuscript.

22 H. Duffy, The War on Terror and the Framework of International Law, pp 18-21.

23 E. Stubbins Batesand et al, 'Terrorism and International Law, Accountability', Remedies and Reforms, p 4.

24 Article 2 of International Convention for the Suppression of Acts of Nuclear Terrorism.

25 United Nations Office of Drugs and Crime (UNODC), "Frequently Asked Questions on International Law Aspects of CounterTerrorism," 2009, United Nations, New York, p 17.

26 Measures to Prevent International Terrorism, 1989.

27 R. Young, 'Defining Terrorism: The Evolution of Terrorism as a Legal Concept in International Law and Its Influence on Definitions in Domestic Legislation,' pp 38-39.

28 Measures to Eliminate International Terrorism, 1994.

29 Declaration on Measure to Eliminate International Terrorism of 1994, 1(3).

30 Measures to Eliminate International Terrorism, 1996.

31 J. Trahan, 'Terrorism Conventions: Existing Gaps and Different Approaches' (2002) 8 New England and International and Comparative Law Annual.

32 Declaration on Measure to Eliminate International Terrorism of 1996, 1(2).

33 International Convention for the Suppression of the Financing of Terrorism, 2000.

34 Article 2 of United Nations General Assembly Resolution 54/109.

35 United Nations General Assembly, (2 December 2004), Follow-up to the Outcome of the Millennium Summit.

36 United Nations General Assembly, (2 December 2004), Follow-up to the Outcome of the Millennium Summit, Secretary General, A/ RES/59/565, Para 164.

37 United Nations Office Drug and Crime (UNODC), 'Frequently Asked Question on International Law Aspects of Counter terrorism', p 19.

38 J. Boulden, et al, 'Terrorism and the UN: before and after September 11' (2004) Indiana University Press, p 57.

39 Article 2(e) of United Nations Security Council Resolution No 1373 (2001).

40 Article 3(g) of United Nations Security Council Resolution No 1373 (2001).

41 United Nations, 2001The Security Council Unanimously Adopts Wide-ranging Anti-terrorism Resolution; Calls for Suppressing Financing, Improving International Cooperation.
42 United Nations Security Council Resolution No. 1540, para I.

43 United Nations Security Council Resolution 1540.

44 United Nations Security Council Resolution 1566

45 R. Young, 'Defining Terrorism: The Evolution of Terrorism as a Legal Concept in International Law and Its Influence on Definitions in Domestic Legislation', pp 44-47.

46 United Nations Security Council Resolution 1526.

47 Judgment of International Court of Justice in the case concerning Corfu Channel, Merits, Judgement ICJ Reports 1949 and the Courts Judgement in the case concerning Nicaragua v United States of America, ICJ Reports 1986.

48 Article 51, Paras 232-236, United Nations Charter.

49 Statute of the International Law Commission, Article, 1 (adopted by the General Assembly 174 (II) of 21 November 1947 as Amended by Resolutions 485 (V) of 12 December 1950, 984(X) of 3 December 1955,985 (X) of 3 December 1955 and 36/39 of 18 November 1981).

50 United Nations, the Work of the International Law Commission, Vol. I, New York: United Nations Publication, 2007, pp 103-104.

51 Judgment International Military Tribunal (Nuremberg), 1 October 1946, pp 12-14.

52 Draft Code of Crime against the Peace and Security of Mankind with commentaries. 1996. Art 20(6). (Text adopted by International Law Commission at its fourty-eighth session, in 1996).

53 International Criminal Court the Official Website, http://icc-cpi. int $>$ accessed (24 December 2018).

54 Rome Statute of the International Criminal Court, Article 5 (adopted 17 July 1998, entered into force 1 July 2002).

55 R. J. Goldstone et al, 'Evaluating the Role of the International Criminal Court as a Legal Response to Terrorism' (2003) 16 Harvard Human Right Journal, p 14.

56 United Nations Office of Drugs and/Crimes (UNODC), 'Frequently Asked Questions on International Law Aspects of Counter terrorism', p 16.

57 SAARC Convention on the Suppression of Terrorism (adopted 4 November 1987).

58 European Convention on the Suppression of Terrorism (adopted 27 January 1977, entered into force 4 August 1978) EUTS.

59 Article 421(1), French Penal Code (Amendment) 2016.

60 D. O'Donnell, 'International Treaties against Terrorism and the Use of Terrorism during Armed Conflict and by Armed Forces' (2006) 88(864) International Review of the Red Cross, pp 853-857.

\section{REFERENCES}

Moghadam et al. 2006. The Roots of Terrorism. Infobase Publishing.

Abbasi, I. et al. 2014. An overview of the political theories of terrorism. Journal of Humanities and Social Science 19IOSR: 103-107.

Anti-Terrorism Conventions at International Level, of this Manuscript.

Article 2 of International Convention for the Suppression of Acts of Nuclear Terrorism.

Article 2 of United Nations General Assembly Resolution 54/109.

Article 2(e) of United Nations Security Council Resolution No 1373 (2001).

Article 3(g) of United Nations Security Council Resolution No 1373 (2001).

Article 421(1), French Penal Code (Amendment) 2016

Article 51, Paras 232-236, United Nations Charter

Article 7, the United Nations Charter.

Batesand, E. S. et al. 'Terrorism and International Law, Accountability', Remedies and Reforms, p 4.

Boulden, J. et al. 2004. Terrorism and the UN: Before and After September 11. Indiana University Press.

Bowden, B. 2007. The terror(s) of our time(s). Social Identities 13(4): 541-554. 
Ciment, J. 2015. World Terrorism: an Encyclopedia of Political Violence from Ancient Times to the Post-9/11 era. Routledge.

Coady, C. A. 2004. Terrorism and innocence. The Journal of Ethics 8 (1): 37-58.

Declaration on Measure to Eliminate International Terrorism of 1994, 1(3).

Declaration on Measure to Eliminate International Terrorism of 1996, 1(2).

Draft Code of Crime against the Peace and Security of Mankind with commentaries. 1996. Art 20(6). (Text adopted by International Law Commission at its fourty-eighth session, in 1996).

European Convention on the Suppression of Terrorism (adopted 27 January 1977, entered into force 4 August 1978) EUTS.

Goldstone, R. J. et al. 2003. Evaluating the role of the international criminal court as a legal response to terrorism. Harvard Human Right Journal 16.

Hoffman B, 1999. Terrorism Trends and Prospects. Countering the new terrorism, $\mathrm{p} 13$.

International Convention for the Suppression of the Financing of Terrorism, 2000.

International Criminal Court the Official Website, http://icc-cpi. int $>$ accessed (24 December 2018).

Jackson, R. 2011. In defence of 'terrorism': Finding a way through a forest of misconceptions. Behavioral Sciences of Terrorism and Political Aggression 3(2): 116-130.

Judgment International Military Tribunal (Nuremberg), 1 October 1946, pp 12-14.

Judgment of International Court of Justice in the case concerning Corfu Channel, Merits, Judgement ICJ Reports 1949 and the Courts Judgement in the case concerning Nicaragua v United States of America, ICJ Reports 1986.

Saul, B. 2006. Defining Terrorism in International Law. New York: Oxford University Press.

Schmid, C. P. et al. Political Terrorism, A New Guide to Actors, Authors, Concept, Databases, Theories, and Literature, p 28.

O'Donnell, D. 2006. International treaties against terrorism and the use of terrorism during armed conflict and by Armed Forces. International Review of the Red Cr 88(864).

Sorel, J. M. 2003. Some Question about the Definition of Terrorism and the Fight against Its Financing. European Journal of International Law (EJIL) 14 (2): 366-369.

Trahan, J. 2002. Terrorism conventions: Existing gaps and different approaches. New England and International and Comparative Law Annual 8.

Marshall, M. G. 2002. Global Terrorism: an Overview and Analysis. Center for International Development and Conflict Management, College Park: University of Maryland.

Measures to Eliminate International Terrorism, 1994.

Measures to Eliminate International Terrorism, 1996.

Measures to Prevent International Terrorism, 1989.

Rome Statute of the International Criminal Court, Article 5 (adopted 17 July 1998, entered into force 1 July 2002)

SAARC Convention on the Suppression of Terrorism (adopted 4 November 1987).

Schmid, A. P. et al. 2005. Political Terrorism: A Research Guide to Concepts, Theories, Data Bases and Literature. New Jersey: Transaction Publishers Rutgers.

Statute of the International Law Commission, Article, 1 (adopted by the General Assembly 174 (II) of 21 November 1947 as
Amended by Resolutions 485 (V) of 12 December 1950, 984(X) of 3 December 1955, 985(X) of 3 December 1955 and $36 / 39$ of 18 November 1981).

The United Nations, The United Nations Emerged after World War II as an International Peacekeeping Organization. https://www.khanacademy.org/hu manities/us-history/riseto-world-power/us-wwii/a/the-united-nations $>$ accessed (24 June 2019).

United Nations General Assembly, (2 December 2004), Followup to the Outcome of the Millennium Summit.

United Nations General Assembly, (2 December 2004), Followup to the Outcome of the Millennium Summit, Secretary General, A/RES/59/565, Para 164.

United Nations Office Drug and Crime (UNODC), 'Frequently Asked Question on International Law Aspects of Counter terrorism', p 19.

United Nations Office of Drugs and /Crimes (UNODC), 'Frequently Asked Questions on International Law Aspects of Counter terrorism', p 16.

United Nations Office of Drugs and Crime (UNODC), "Frequently Asked Questions on International Law Aspects of Counter- Terrorism," 2009, United Nations, New York, p 17.

United Nations Office on Drugs and Crime, Defining Terrorism, 2018, https://www.unodc.org/e4j/en/terrorism/module-4/ key-issues/defining-terrorism.html $>$ accessed (12 January 2019).

United Nations Security Council Resolution 1526.

United Nations Security Council Resolution 1540.

United Nations Security Council Resolution 1566.

United Nations Security Council Resolution No. 1540, para I.

United Nations, 2001. The Security Council Unanimously Adopts Wide-ranging Anti-terrorism Resolution; Calls for Suppressing Financing, Improving International Cooperation.

United Nations, 2007. The Work of the International Law Commission, Vol. I, New York: United Nations Publication, pp 103-104.

Weinberg, L., Pedahzur, A. \& Hirsch-Hoefler, S. 2004. The challenges of conceptualizing terrorism. Terrorism and Political Violence 16(4): 777-794.

Whittacker, D. J. 2004. Terrorist and Terrorism in the Contemporary World. UK: Routledge.

Wyper, L. E. 2014. Transformative leadership and diversity: The need for change agents, followership, and tipping points in our educational institutions. Journal of Global Citizenship \& Equity Education 4(1): 4-5.

Young, R. 'Defining Terrorism: The Evolution of Terrorism as a Legal Concept in International Law and Its Influence on Definitions in Domestic Legislation,' pp 38-39.

Muhammad Imran

Faculty of Law

Universiti Kebangsaan Malaysia

43600 UKM Bangi, Selangor

Rohaida Nordin

Faculty of Law

Universiti Kebangsaan Malaysia

43600 UKM Bangi, Selangor

Email: rohaidanordin@ukm.edu.my 